\title{
Pengaruh Komunikasi Interpersonal Terhadap Kinerja Resepsionis di Qunci Villas Hotel, Lombok - NTB
}

\author{
Irfal \\ Sekolah Tinggi Pariwisata Trisakti \\ Email : irfal@stptrisakti.ac.id
}

\begin{abstract}
ABSTRAK
Komunikasi yang efektif merupakan hal yang dapat mengubah sikap dari orang-orang yang terlibat untuk berkomunikasi dengan orang-orang disekitarnya. Komunikasi di hotel sangat penting, baik dengan tamu dalam maupun luar. Resepsionis hotel merupakan fasilitator antara tamu dan hotel yang fungsinya untuk menjalin hubungan atau penghubung antara tamu dengan pihak manajemen hotel, oleh karena itu resepsionis harus mampu berkomunikasi dengan baik dan memahami apa yang diinginkan tamu dalam komunikasi dan empati terhadap apa yang dirasakan tamu. Sehubungan dengan hal tersebut, maka penelitian ini dibuat dan tujuan utama dari penelitian ini adalah untuk melihat bagaimana pengaruh keterampilan komunikasi interpersonal pada resepsionis di Qunci Villas Hotel. Penelitian ini menggunakan metode kuantitatif dengan pendekatan korelasional dan mengambil 50 responden. Hasil penelitian ini menunjukkan bahwa komunikasi interpersonal berpengaruh positif dan signifikan terhadap kinerja Receptionist di Qunci Villas Hotel. Sub variabel dominan komunikasi interpersonal terbuka, sub variabel dominan kinerja Resepsionis adalah Kualitas.
\end{abstract}

Kata Kunci: Kinerja, Komunikasi Interpersonal

\section{PENDAHULUAN}

Komunikasi merupakan hal yang penting dalam kehidupan manusia. Manusia sebagai mahluk sosial membutuhkan komunikasi dalam kesehariannya. Komunikasi bisa terjadi secara personal, interpersonal, maupun kelompok. Seseorang yang berkomunikasi dengan orang lain membutuhkan keahlian tertentu. Hal ini dikarenakan pemahaman setiap orang yang diajak berkomunikasi berbeda-beda. Kemampuan berkomunikasi perlu dipelajari dan diasah karena bukanlah kemampuan yang dibawa sejak lahir. Kemampuan ini didapatkan berdasarkan kemauan yang keras untuk belajar dan mencoba. Kemampuan berkomunikasi penting untuk dimiliki karena merupakan salah satu kunci sukses yang dibutuhkan pada masa ini yang penuh persaingan.

Komunikasi dianggap efektif apabila komunikasi tersebut dapat menghasilkan perubahan sikap (attitude change) pada orang yang terlibat dalam komunikasi. Komunikasi yang efektif melibatkan adanya pertukaran informasi, ide, kepercayaan, perasaan dan sikap antara dua orang yang hasilnya sesuai dengan harapan. Menurut DeVito (2011), indikator dalam komunikasi interpersonal yang efektif adalah keterbukaan (openness), empati (empathy), dukungan (supportiveness), rasa positif (possitiveness), kesetaraan (equality). Kemampuan untuk dapat berkomunikasi secara interpersonal dibutuhkan oleh beberapa profesi demi menunjang karirnya, salah satunya adalah bagian resepsionis di hotel.

Resepsionis merupakan bagian yang paling mudah dicari dan dilihat oleh tamu karena letaknya di bagian depan. Menurut Bagyono (2017), resepsionis merupakan petugas hotel yang tugas utamanya melayani tamu yang akan check-in dan memprosesnya hingga memperoleh kamar yang diinginkan dengan cara yang menyenangkan. Resepsionis merupakan fasilitator antara tamu dengan pihak hotel. Oleh karena itu resepsionis harus mampu berkomunikasi secara interpersonal dengan tamu hotel. Pemberian informasi yang benar dan tepat harus bisa dilakukan untuk menghindari adanya keluhan tamu. Biasanya tamu akan sangat sensitif terhadap pertanyaan yang tidak bisa dijawab oleh resepsionis. 
Selain menjadi fasilitator antara pihak hotel dan tamu (eksternal), resepsionis juga berperan sebagai fasilitator dengan departemen lain (internal). Resepsionis memegang peranan penting karena berhubungan dengan aktivitas hotel, baik secara langsung maupun tidak langsung. Tanggung jawab dalam memberikan kesan baik atau buruk kepada tamu hotel menuntut resepsionis harus tampil sigap, tepat dan penuh kesiapan.

Kedudukan resepsionis yang strategis membuat kehandalan dalam berkomunikasi memegang peran penting, baik secara internal maupun eksternal. Peran penting keterampilan komunikasi secara interpersonal pada resepsionis juga dibahas mendalam oleh Kimiawan (2020) dalam jurnalnya. Dalam jurnalnya disimpulkan bahwa resepsionis harus memiliki 2 (dua) pengetahuan, yaitu pengetahuan umum dan pengetahuan khusus, dimana untuk kedua pengetahuan ini memerlukan keterampilan berkomunikasi. Secara internal, resepsionis yang memiliki keterampilan berkomunikasi mampu memahami struktur organisasi hotel dan berkoordinasi dengan departemen lain. Secara eksternal, keterampilan berkomunikasi interpersonal yang baik bisa untuk memahami tamu hotel yang mempunyai kultur dan latar belakang yang berbeda dan berkomunikasi dalam bahasa internasional.

Resepsionis merupakan pusat kegiatan hotel dan berhubungan dengan banyak orang secara internal dan eksternal, dengan kemampuan berkomunikasi interpersonal yang baik akan membuat kinerjanya tampil baik juga Febriyani dan Puspasari (2018). Poin penting dari kinerja resepsionis di hotel adalah memberikan pelayanan yang efektif, efisien dan maksimal dengan tetap mengedepankan kenyamanan dan kepuasan tamu, baik sebelum tamu menginap, ketika menginap dan ketika tamu tersebut hendak meninggalkan hotel. Hal ini memperlihatkan bahwa resepsionis mempunyai peran penting dalam keberlangsungan sebuah hotel. Oleh karena itu perlu dilakukan penelitian lebih mendalam mengenai pengaruh komunikasi interpersonal terhadap kinerja resepsionis.

Qunci Villas Hotel terletak di Jalan Raya Mangsit, Senggigi, Lombok. Hotel tropis ini merupakan hotel bintang empat yang terletak persis di Pantai Mangsit. Hotel ini memberikan kemewahan dan berkomitmen untuk tidak hanya menjual kamar hotel dan makanan di restaurant, tetapi juga memberikan pelayanan personal yang baik dimana tamu yang menginap dapat merasakan dan kenyamanan yang berbeda apabila dibandingkan dengan hotel-hotel lainnya. Hotel juga menawarkan beberapa tipe kamar, seperti Ocean View, Garden View, Partial Ocean View.

\section{Tujuan Penelitian}

1. Mengetahui kemampuan resepsionis dalam berkomunikasi secara interpersonal di Qunci Villas Hotel Lombok.

2. Mengetahui kinerja resepsionis di Qunci Villas Hotel Lombok.

3. Mengetahui sejauhmana pengaruh kemampuan berkomunikasi secara interpersonal terhadap kinerja resepsionis di Qunci Villas Hotel Lombok.

\section{TINJAUAN PUSTAKA}

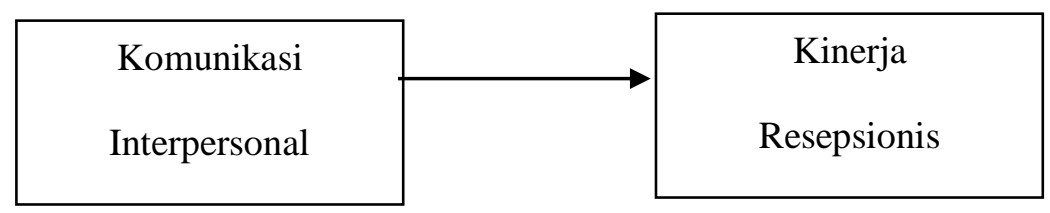

Gambar 1. Kerangka Berpikir

\section{Komunikasi Interpersonal}

Dalam berkomunikasi, penyampai pesan (komunikator) berusaha untuk menyampaikan pesan, informasi, pikiran, gagasan dan pendapat kepada penerima pesan (komunikan), baik individu maupun kelompok. Komunikasi memerlukan adanya timbal balik antara komunikator dan komunikan. Menurut Ngalimun (2018), komunikasi merupakan proses penyampaian pesan oleh seseorang kepada orang lain untuk memberitahu, mengubah sikap, pendapat atau perilaku baik langsung secara lisan maupun tidak langsung melalui media. 
Menurut Carl I. Hovland (1953), ilmu komunikasi adalah upaya yang sistematis untuk merumuskan secara tegas asas-asas penyampaian informasi serta pembentukan pendapat dan sikap. Ada beberapa unsur dalam komunikasi interpersonal, diantaranya sumber (sources) yang sering juga disebut sebagai pengirim atau sender, penyandi (encoder), komunikator (communicator). Dalam menyampaikan pesan, penyampai pesan memerlukan saluran atau media. Beberapa istilah yang sering juga digunakan adalah penerima (receiver) atau sasaran/tujuan (destination), penyandi balik (decoder) atau khalayak (audience), pendengar (listener), penerima pesan atau penafsir (interpreter).

Komunikasi interpersonal adalah komunikasi secara tatap muka yang dilakukan antar orang, yang mengakibatkan setiap yang terlibat dalam komunikasi menangkap reaksi orang lain secara langsung. Dimana reaksi tersebut dapat dilihat baik secara verbal ataupun non verbal. Menurut Wood (2013) semua komunikasi, kecuali komunikasi intrapersonal, adalah komunikasi interpersonal. Komunikasi interpersonal meliputi:

1. Selektif, artinya memilih lawan bicara atau dengan siapa akan berkomunikasi.

2. Sistemik, artinya komunikasi dipengaruhi oleh sistem, seperti: budaya, pengalaman pribadi dan lain-lain.

3. Unik, artinya hubungan dalam komunikasi akan berkembang sesuai ritme dan pola tersendiri yang khas, tergantung lawan bicaranya.

4. Prosesual, artinya komunikasi merupakan proses jangka panjang yang terus berlangsung (on going) dan berkesinambungan (continuous).

5. Transaksi artinya komunikasi merupakan proses transaksi yang berlangsung kontinyu dan bersamaan (simultancously).

Komunikasi interpersonal merupakan salah satu pola komunikasi yang efektif untuk mempengaruhi dan mengubah sikap dan perilaku seseorang. Komunikasi interpersonal memiliki 2 (dua) fungsi, yaitu fungsi sosial dan fungsi pengambilan keputusan.

1. Fungsi Sosial

a. Komunikasi berguna untuk memenuhi kebutuhan, baik biologis dan psikologis.

b. Komunikasi merupakan salah satu kewajiban sosial.

c. Komunikasi dapat mengembangkan hubungan timbal balik.

d. Komunikasi dapat meningkatkan mutu diri sendiri.

e. Komunikasi sebagai salah satu cara menyelesaikan konflik.

2. Fungsi Pengambilan Keputusan

a. Komunikasi digunakan untuk memberikan informasi.

b. Komunikasi dilakukan untuk mempengaruhi orang lain.

Dalam melakukan komunikasi yang efektif akan terjadi pertukaran informasi, ide, kepercayaan, perasaan dan sikap antara penerima dan pemberi pesan, yang hasilnya sesuai dengan harapan. Hasil yang akan didapatkan dari komunikasi yang efektif adalah adanya perubahan sikap (attitude change) pada setiap individu yang terlibat dalam komunikasi tersebut. Menurut DeVito (2011), komunikasi interpersonal yang efektif memiliki 5 (lima) indikator, yaitu:

1. Keterbukaan (openness) dapat menciptakan keefektifan dalam melakukan komunikasi interpersonal. Dengan adanya keterbukaan, pihak yang terlibat dalam komunikasi interpersonal akan menanggapi setiap informasi yang diterimanya dengan senang hati.

2. Empati (empathy) merupakan suatu proses ketika pihak yang berkomunikasi mampu memahami dan merasakan apa yang dirasakan (perasaan) oleh lawan bicaranya, serta menangkap arti perasaan itu. Setelah itu mampu mengkomunikasikannya kembali dengan kepekaan sehingga menunjukkan sikap mengerti atas perasaan yang dialami lawan bicaranya.

3. Dukungan (supportiveness) dapat menciptakan situasi yang terbuka selama proses komunikasi sehingga bisa menciptakan komunikasi yang efektif.

4. Rasa Positif (possitiveness) mampu menciptakan situasi berkomunikasi yang kondusif. Pihak yang terlibat dalam komunikasi mampu memperlihatkan perasaan positif terhadap diri sendiri dan 
lawan bicaranya sehingga mampu mendorong lawan bicara lebih aktif berpartisipasi selama proses komunikasi berlangsung.

5. Kesetaraan (equality) membuat pihak yang erlibat dalam komunikasi merasakan adanya penghargaan dari lawan bicaranya, sehingga kedua belah pihak merasa penting dan dihargai.

\section{Kinerja Karyawan}

Nurlaila (2010) menyatakan bahwa kinerja adalah hasil konkret yang dapat diamati dan dapat diukur. Kinerja karyawan berkaitan dengan hasil kerja dan perilaku, dimana penilaian kinerja karyawan mengacu pada suatu sistem yang formal dan terstruktur. Melalui penilaian kinerja, karyawan dapat dinilai dan diukur pekerjaan, perilaku maupun hasil kerjanya. Kinerja karyawan merupakan salah satu aspek yang penting bagi organisasi karena berkembang atau tidaknya suatu organisasi juga dipengaruhi oleh kinerja karyawannya.

\section{Karakteristik Kinerja Karyawan}

Menurut Mangkunegara (2012), kinerja karyawan berkorelasi dengan tanggung jawab, pengambilan keputusan, tanggung jawab, perencanaan kerja dan sikap berjuang dalam mencapai tujuan. Jadi karyawan dengan kinerja yang tinggi akan memiliki sikap kerja yang bertanggung jawab, berani mengambil keputusan dan menanggung resikonya, membuat tujuan dan rencana kerja yang menyeluruh serta berjuang untuk mencapai tujuan itu, memanfaatkan umpan balik (feed back) yang diterima dari seluruh kegiatan kerja yang dilakukannya, serta berusaha menggunakan setiap kesempatan untuk merealisasikan rencananya.

Untuk mengukur kinerja karyawan secara individu, menurut Robbins (2017) ada 6 (enam) indikator, yaitu:

1. Kualitas Kerja

Diukur dari bagaimana karyawan mempersepsikan kualitas pekerjaan yang dihasilkannya serta menggunakan keterampilan dan kemampuan untuk menampilkan hasil kerja yang sempurna.

2. Kuantitas Kerja

Diukur dari jumlah yang dihasilkan. Biasanya dapat terlihat dari: jumlah unit, jumlah siklus aktivitas yang diselesaikan.

3. Ketepatan waktu

Diukur dari waktu awal dilakukan aktivitas sampai tingkat aktivitas tersebut diselesaikan. Biasanya dapat dilihat dari hasil output dan kemampuan karyawan dalam memaksimalkan waktu yang tersedia untuk melakukan aktivitas lain.

4. Efektivitas

Diukur dari kemampuan memaksimalkan penggunaan sumber daya yang ada di organisasi (tenaga, uang, teknologi, bahan baku). Tujuannya adalah untuk menaikkan hasil dari setiap unit dalam penggunaan sumber daya.

5. Kemandirian

Diukur dari kemampuan karyawan dalam menjalankan fungsi kerjanya.

6. Komitmen kerja

Diukur dari kemampuan karyawan melakukan tanggung jawabnya dan mempunyai komitmen kerja dengan instansi/lembaga tempatnya bekerja.

\section{Kinerja Resepsionis}

Resepsionis adalah sebuah bagian dari Departemen Front Office dari sebuah hotel, pusat dari segala aktivitas hotel. Pada bagian inilah tamu yang pertama kali datang ke hotel akan langsung menuju ke resepsionis untuk mencari kamar. Disamping itu tamu juga dapat mencari segala bentuk informasi mengenai hotel maupun informasi di luar hotel, informasi yang dapat diketahui oleh tamu mengenai fasilitas kamar, berbagai macam kamar sampai fasilitas yang dimiliki hotel. Selain bertugas menerima tamu, reseptionis juga mendapatkan penghasilan utama dari menjual kamar hotel sekaligus membentuk citra yang baik untuk nama hotel (Saputro dkk, 2014). 
Kinerja resepsionis dapat diukur melalui kemampuannya dalam menjalankan tanggung jawab yang diberikan kepadanya, baik secara kualitas maupun kuantitas. Seorang resepsionis harus memiliki kualifikasi agar dapat memenuhi kualifikasi kerja sehingga menjadi resepsionis yang handal dan profesional. Menurut Febryani dan Puspasari (2018), tolak ukur kinerja resepsionis adalah dalam hal pelayanannya. Resepsionis harus mampu memberikan pelayanan yang maksimal, efektif serta efisien, dengan tetap mengedepankan layanan tamu. Tujuannya adalah agar tamu merasa nyaman puas, baik sebelum menginap, selama menginap sampai tamu tersebut hendak meninggalkan hotel.

\section{Komunikasi Interpersonal dan Kinerja Resepsionis}

Effendi (2010) menyatakan bahwa terdapat pengaruh yang positif dari komunikasi interpersonal terhadap kinerja. Artinya, semakin baik kemampuan karyawan dalam berkomunikasi secara interpersonal maka akan semakin baik kinerjanya. Hal ini juga sejalan dengan hasil penelitian yang dilakukan oleh Gumay dan Hermani (2018) yang menyatakan bahwa variabel komunikasi interpersonal memiliki pengaruh yang signifikan, kuat dan positif terhadap kinerja karyawan.

\section{METODE PENELITIAN}

Penelitian ini menggunakan metode kuantitatif dan pendekatan korelasional. Artinya penelitian ini dilakukan untuk mengetahui ada atau tidaknya hubungan antara dua variabel atau lebih. Penelitian ini merupakan penelitian lapangan yang dilakukan untuk mengetahui pengaruh variabel $\mathrm{X}$ (komunikasi interpersonal) terhadap variabel Y (kinerja) resepsionis di Qunci Villas Hotel, Lombok. Data dalam penelitian ini dilakukan dengan cara menggunakan kuisioner (angket) model skala likert dalam bentuk ceklis yang disebarkan ke responden.

Populasi dalam penelitian ini adalah tamu hotel yang menginap di Qunci Villas Hotel. Proses penyebaran kuisioner di masa pandemi menyebabkan tamu hotel yang menginap berkurang secara drastis. Responden penelitian ini berjumlah 50 orang. Penelitian ini menggunakan skala ordinal. Skala ordinal digunakan untuk mengukur pernyataan para tamu hotel sebagai responden dalam penelitian ini yang menggunakan 5 (lima) tingkatan (sangat setuju, setuju, ragu-ragu, tidak setuju, sangat tidak setuju). Waktu penelitian dilakukan pada bulan September-November 2020 di Qunci Villas Hotel, Lombok, Nusa Tenggara Barat. Kuisioner disebarkan dengan menggunakan google form.

\section{HASIL DAN PEMBAHASAN}

\section{Nilai Mean Variabel Komunikasi Interpersonal dan Kinerja Resepsionis}

Nilai mean yang didapat dari sub variabel komunikasi interpersonal adalah Keterbukaan (3.98), Empati (3.85), Dukungan (3.85), Rasa Positif (3.96) dan Kesetaraan (3.56). Berdasarkan nilai tingkat interval dari skala pengukuran yang digunakan, memperlihatkan responden menilai sub variabel keterbukaan, empati, dukungan dan rasa positif dinilai baik. Untuk variabel kesetaraan juga memperoleh hasil yang cukup baik, hanya saja masih perlu ditingkatkan lagi. Mean tertinggi adalah keterbukaan. Hal ini berarti adanya sikap terbuka dari resepsionis juga membuat para tamu merasa dapat bersikap terbuka terhadap resepsionis. Dengan masing-masing sub variabel yang memperoleh nilai cukup baikmemperlihatkan bahwa resepsionis Qunci Villas Hotel mampu melakukan komunikasi interpersonal dengan baik terhadap para tamu hotel.

Nilai mean yang didapat dari sub variabel kinerja resepsionis adalah Kualitas (3.99), Kuantitas (3.95), Ketepatan (3.85), Efektifitas (3.78), Kemandirian (3.76), Komitmen Kerja (3.78). Berdasarkan nilai tingkat interval dari skala pengukuran yang digunakan, memperlihatkan responden menilai sub variabel kualitas, kuantitas, ketepatan, efektifitas, kemandirian dan komitmen kerja dinilai baik. Mean tertinggi adalah sub variabel kualitas. Hal ini berarti para tamu di Qunci Villas Hotel menilai kualitas kerja resepsionis sudah baik. Kualitas disini meliputi pengetahuan seputar informasi mengenai hotel, kemampuan bersikap, kemampuan berpenampilan dan keterampilan yang dibutuhkan untuk bekerja di resepsionis. Dengan masing-masing sub variabel yang memperoleh nilai cukup baik memperlihatkan bahwa resepsionis Qunci Villas Hotel mampu menampilkan kinerja yang baik ketika melayani para tamu hotel. 


\section{Uji Validitas Butir Kuisioner Komunikasi Interpersonal}

Berdasarkan hasil dari uji validitas dihasilkan bahwa statistik data validitas variable independen komunikasi interpersonal $(\mathrm{X})$ yang terdiri dari $\mathrm{X}_{1}, \mathrm{X}_{2}, \mathrm{X}_{3}$, sampai $\mathrm{X}_{20}$ semuanya menghasilkan data ( $\left.\mathrm{t}_{\text {hitung }}\right)>$ daripada ( $\left.\mathrm{t}_{\text {tabel }}\right)$ sebesar 0,279 dengan faktor korelasi kesalahan 5\% $(\alpha=0,05)$. Sehingga, semua butir kuisioner komunikasi interpersonal dinyatakan valid.

\section{Uji Validitas Butir Kuisioner Kinerja Resepsionis}

Berdasarkan hasil dari uji validitas dihasilkan bahwa bahwa statistik data validitas kuisioner dari variabel dependen kinerja recepsionis $(\mathrm{Y})$ yang terdiri dari $\mathrm{Y}_{1}, \mathrm{Y}_{2}, \mathrm{Y}_{3}$, sampai $\mathrm{Y}_{20}$ sebanyak 19 butir soal kuisioner menghasilkan data $\left(\mathrm{t}_{\text {hitung }}\right)<$ daripada $\left(\mathrm{t}_{\text {tabel }}\right)$ sebesar 0,279 dengan faktor korelasi kesalahan 5\% $(\alpha=0,05)$, sehingga dinyatakan valid. Sedangkan, ketidakvalidan terjadi pada butir soal no.3, hal ini bisa dikarenakan setiap responden berbeda-beda menilai berpakaian rapi atau tidaknya seorang resepsionis.

\section{Uji Normalitas}

Berdasarkan hasil uji normalitas didapatkan hasil 0.516. Karena hasil 0.516 lebih besar daripada 0.05 maka data penelitian dinyatakan berdistribusi normal.

\section{One-Sample Kolmogorov-Smirnov Test}

\begin{tabular}{|ll|r|}
\hline & & $\begin{array}{c}\text { Unstandardized } \\
\text { Residual }\end{array}$ \\
\hline $\mathrm{N}$ & Mean & 50 \\
Normal Parameters & a,b & Std. Deviation \\
& Absolute & 4.24447317 \\
Most Extreme Differences & Positive & .116 \\
& Negative & .058 \\
Kolmogorov-Smirnov Z & & -.116 \\
Asymp. Sig. (2-tailed) & & .817 \\
\hline
\end{tabular}

a. Test distribution is Normal.

b. Calculated from data.

\section{Uji Reliabilitas}

\section{Reliability Statistics}

\begin{tabular}{|r|r|}
\hline $\begin{array}{c}\text { Cronbach's } \\
\text { Alpha }\end{array}$ & N of Items \\
\hline .925 & 40 \\
\hline
\end{tabular}

Berdasarkan hasil uji reliabilitas komunikasi interpersonal dengan kinerja resepsionis diperoleh hasil data Alpha Cronbach's sebesar 0,925. Dikarenakan hasil Alpha Cronbach's lebih besar dari 0,6 maka data tersebut dinyatakan reliabel.

\section{Uji Regresi Linier}

Berdasarkan analisis data dengan menggunakan SPSS 20, maka diperoleh hasil persamaan regresi sebagai berikut : $\quad \mathrm{Y}=29.140+0.627+\mathrm{e}$

\section{Coefficients $^{\mathrm{a}}$}

\begin{tabular}{|rl|r|r|r|r|r|}
\hline \multirow{2}{*}{ Model } & \multicolumn{2}{|c|}{$\begin{array}{c}\text { Unstandardized } \\
\text { Coefficients }\end{array}$} & \multicolumn{2}{c|}{$\begin{array}{c}\text { Standardized } \\
\text { Coefficients }\end{array}$} & \multirow{2}{*}{ S } & \multicolumn{1}{|c|}{} \\
\cline { 3 - 5 } & \multicolumn{1}{|c|}{ B } & Std. Error & Beta & & \\
\hline \multirow{2}{*}{1} & (Constant) & 29.140 & 5.866 & & 4.967 & .000 \\
& KOMUNIKASI & .627 & .076 & .766 & 8.247 & .000 \\
\hline
\end{tabular}

a. Dependent Variable: KINERJA RESEPSIONIS (Y) 
Persamaan regresi di atas memperlihatkan hubungan antara variabel independent dengan variabel dependent secara parsial. Dari persamaan tersebut dapat diambil kesimpulan bahwa :

1. Nilai konstanta adalah 29.140 , artinya jika tidak terjadi perubahan variabel komunikasi interpersonal maka kinerja resepsionis di Qunci Villas Hotel, Lombok adalah sebesar 29.140 satuan.

2. Nilai koefisien regresi komunikasi interpersonal adalah 0.627 , artinya jika variabel komunikasi interpersonal meningkat $1 \%$ dan konstanta (a) adalah nol maka kinerja resepsionis akan meningkat sebesar 0.627. Hal tersebut menunjukkan bahwa variabel komunikasi interpersonal berpengaruh terhadap kinerja resepsonis.

\section{Hasil Uji t Parsial}

Berdasarkan uji analisis regresi dengan mengamati baris kolom t dan sig bisa dijelaskan sebagai berikut :

1. Pengaruh Variabel Komunikasi Interpersonal terhadap Kinerja Resepsionis

Variabel komunikasi interpersonal berpengaruh secara positif dan signifikan terhadap kinerja resepsionis di Qunci Villas Hotel. Hal ini terlihat dari signifikan komunikasi interpersonal $0.00<0.05$ dan nilai $t_{\text {tabel }}=2.0106$. Berarti nilai $t_{\text {hitung }}>t$ table $(8.247>2.0106)$. Sehingga hipotesis yang berbunyi terdapat pengaruh komunikasi interpersonal terhadap kinerja resepsionis secara parsial diterima.

2. Hasil Uji Koefisien Determinasi

Koefisien determinasi $\left(\mathrm{R}^{2}\right)$ pada intinya mengukur seberapa jauh kemampuan model dalam menerangkan variasi variabel dependen. Nilai koefisien determinasi adalah nol dan satu. Nilai $\mathrm{R}^{2}$ yang rendah berarti kemampuan variable-variabel independent dalam menjelaskan variable-variabel dependen sangat terbatas. Nilai yang mendekati satu berarti variabel-variabel independent memberikan hamper semua informasi yang dibutuhkan untuk mendeteksi variasi variabel dependen. Berdasarkan uji $\mathrm{R}^{2}$ yang dilakukan diperoleh hasil sebagai berikut :

Model Summary

\begin{tabular}{|l|r|r|r|r|}
\hline $\begin{array}{l}\text { Mode } \\
1\end{array}$ & R & R Square & $\begin{array}{c}\text { Adjusted R } \\
\text { Square }\end{array}$ & $\begin{array}{l}\text { Std. Error of } \\
\text { the Estimate }\end{array}$ \\
\hline 1 & $.766^{\mathrm{a}}$ & .586 & .578 & 4.288 \\
\hline
\end{tabular}

Berdasarkan hasil uji $\mathrm{R}^{2}$ diatas dapat diketahui bahwa nilai koefisien determinasi terdapat pada nilai Adjusted R Square sebesar 0.578. Hal ini berarti kemampuan variabel bebas dalam menjelaskan variabel terikat adalah sebesar $57,80 \%$ sisanya $42.20 \%$ dijelaskan oleh variabel lain yang tidak dibahas dalam penelitian ini.

\section{Pengaruh Kemampuan Interpersonal terhadap Kinerja Resepsionis}

Hasil penelitian pada variabel komunikasi interpersonal memperlihatkan bahwa sebagian besar tamu hotel menyatakan bahwa resepsionis Qunci Villas Hotel memiliki kemampuan berkomunikasi interpersonal yang baik. Sejalan dengan DeVito (2011), resepsionis hotel mampu menampilkan kelima indikator dari komunikasi interpersonal yang efektif. Resepsionis mampu menampilkan sikap terbuka, empati, dukungan, rasa positif dan kesetaraan pada tamu hotel yang datang dan menginap. Keterbukaan memperoleh hasil yang tertinggi dibandingkan aspek lainnya. Hal ini berarti adanya sikap terbuka dari resepsionis juga membuat para tamu dapat bersikap terbuka terhadap resepsionis.

Untuk variabel kinerja, resepsionis Qunci Villas Hotel mampu menampilkan kinerja yang baik. Sejalan dengan Robbins (2017), resepsionis sudah mampu menampilkan ke enam indikator kinerja tersebut ketika melayani tamu hotel. Kualitas kerja, kuantitas, ketepatan, efektifitas, kemandirian dan komitmen kerja resepsionis dinilai baik oleh tamu hotel yang menginap. Kualitas kerja memperoleh hasil yang tertinggi dibandingkan aspek lainnya. Hal ini berarti resepsionis sudah memiliki pengetahuan 
seputar informasi mengenai hotel, kemampuan bersikap, kemampuan berpenampilan dan keterampilan yang dibutuhkan untuk bekerja di resepsionis.

Uji statistik pengaruh komunikasi interpersonal terhadap kinerja resepsionis dilakukan untuk mengetahui apakah baik atau tidaknya komunikasi interpersonal dapat mempengaruhi tinggi rendahnya kinerja resepsionis. Berdasarkan hasil uji statistik diperoleh hasil variabel komunikasi interpersonal berpengaruh secara positif dan signifikan terhadap kinerja resepsionis di Qunci Villas Hotel. Artinya, semakin baik kemampuan resepsionis dalam berkomunikasi secara interpersonal maka akan semakin baik pula kinerjanya. Hal ini juga sejalan dengan hasil penelitian yang dilakukan oleh Gumay dan Hermani (2018) yang menyatakan bahwa variabel komunikasi interpersonal memiliki pengaruh yang signifikan, kuat dan positif terhadap kinerja karyawan.

\section{KESIMPULAN}

1. Sub variabel keterbukaan merupakan yang paling menonjol dalam komunikasi interpersonal di Qunci Villas Hotel dengan nilai mean 3.98. Hal ini memperlihatkan bahwa resepsionis dan para tamu bisa saling terbuka dalam memberikan dan menyampaikan keluhannya.

2. Sub variabel kualitas merupakan yang paling menonjol dalam kinerja resepsionis di Qunci Vilas Hotel dengan mean 3.99. Hal ini memperlihatkan resepsionis sudah mampu berperilaku, berpenampilan, memiliki pengetahuan tentang hotel dan memiliki kemampuan yang memadai sebagai resepsionis.

3. Variabel komunikasi interpersonal berpengaruh secara positif dan signifikan terhadap kinerja resepsionis di Qunci Villas Hotel, sehingga hipotesis yang berbunyi terdapat pengaruh komunikasi interpersonal terhadap kinerja resepsionis secara parsial diterima.

\section{SARAN}

1. Sub variabel kemandirian memperoleh penilaian yang terkecil (3.76). Sub variabel ini meliputi kemandirian dalam menghadapi komplain dan pemberian solusi yang berhubungan dengan permasalahan tamu. Oleh karena itu perlu diberikan training mengenai handling complain.

2. Penelitian ini dilakukan disaat pandemi, dimana pihak hotel melakukan pengurangan karyawan di beberapa bagian, salah satunya di bagian resepsionis. Adanya kekurangan SDM akan mempengaruhi juga penilaian tamu hotel dalam mengisi kuisioner dalam penelitian ini. Oleh karena itu perlu juga dilakukan penelitian yang serupa dalam kondisi yang normal.

3. Berdasarkan uji koefisien determenasi, didapatkan hasil $42.20 \%$ dipengaruhi oleh faktor-faktor lain yang tidak masuk dalam penelitian ini. Maka untuk penelitian selanjutnya dapat diteliti faktor-faktor yang mungkin mempunyai pengaruh terhadap kinerja resepsionis hotel.

\section{REFERENSI}

Bagyono. (2017). Teori \& Praktik Hotel Front Office. Bandung: CV. Alfabeta.

DeVito, J. A. (2011). Komunikasi Antar Manusia. Jakarta: Kharisma Publishing.

Effendy. (2010). Komunikasi Teori dan Praktek. Jakarta: PT Grasindo Rosdakarya.

Febriyani, L., \& Puspasari, D. (2018). Analisis Kinerja Resepsionis dalam Layanan Tamu di Front Office Department Hotel Sahid Surabaya. Jurnal Hasil Riset UNESA, 1 (1), 1-11.

Gumay, A.S., \& Hermani, A.D.S. (2018). Pengaruh Komunikasi Interpersonal Terhadap Kinerja Karyawan PT. EURO Management Indonesia. Jurnal Administrasi Bisnis, 7 (2), 68-77.

Hovland, Carl I., Irving K. Janis, and Harold H., Kelley (1953),Communication and Persuasion, New Haven, CT: Yale University Press.

Kimiawan, T.O.S. (2020). Soft Skill Komunikasi Resepsionis. Jurnal Oratio Directa, 2 (2), 330-345.

Mangkunegara, A.P. (2012). Evaluasi Kinerja Sumber Daya Manusia. Bandung: PT Revika Aditama.

Ngalimun. (2018). Komunikasi Interpersonal. Yogyakarta: Pustaka Pelajar

Nurdin, Ali. (2020). Teori Komunikasi Interpersonal. Jakarta: Gramedia. 
Nurlaila, (2010). Manajemen Sumber Daya Manusia I. Ternate: LepKhair.

Robbins, S.P. (2017). Perilaku Organisasi. Jakarta: Salemba Empat.

Saputro, F., \& Putri, E.D.H. (2014). Aktivitas Receptionist dalam Menangani Tamu Personal di Ameera Boutique Hotel Yogyakarta. Jurnal Khasanah Ilmu. 5 (2), 13-24.

Wood, J.T. (2013). Komunikasi Interpersonal Dalam Interaksi Keseharian. Jakarta: Salemba Humanika. 